\title{
The origins of prescribed burning in Scandinavian forestry: the seminal role of Joel Wretlind in the management of fire-dependent forests
}

\author{
Sarah $\operatorname{Cogos}^{1,2} \mathbb{D} \cdot$ Samuel Roturier ${ }^{1} \cdot$ Lars Östlund $^{2}$
}

Received: 30 August 2019 / Revised: 18 November 2019 / Accepted: 23 November 2019 / Published online: 28 November 2019

(c) The Author(s) 2019

\begin{abstract}
In Sweden, prescribed burning was trialed as early as the 1890s for forest regeneration purposes. However, the origins of prescribed burning in Sweden are commonly attributed to Joel Efraim Wretlind, forest manager in the State Forest district of Malå, Västerbotten County, from 1920 to 1952. To more fully understand the role he played in the development of prescribed burning and the extent of his burning, we examined historical records from the State Forest Company's archive and Wretlind's personal archive. The data showed that at least 11,208 ha was burned through prescribed burning between 1921 and 1970, representing $18.7 \%$ of the Malå state-owned forest area. Wretlind thus created a new forestry-driven fire regime, reaching, during peak years, extents close to historical fire regimes before the fire suppression era, and much higher than present-day burning. His use of prescribed fire to regenerate forests served as a guide for many other forest managers, spreading to all of northern Sweden during the 1950-1960s. Our analysis of Wretlind's latest accounts also shows how he stood against the evolutions of modern forestry to defend a forestry system based on the reproduction of natural processes, such as fire.
\end{abstract}

Keywords Prescribed burning $\cdot$ Fire management $\cdot$ Historical fire regime $\cdot$ Boreal forest $\cdot$ Northern Sweden

\section{Introduction}

It is today recognized that humans have influenced and shaped fire regimes, i.e., the set of biophysical parameters characterizing the pattern of fire occurrence in time

Communicated by Juergen Bauhus.

Electronic supplementary material The online version of this article (https://doi.org/10.1007/s10342-019-01247-6) contains supplementary material, which is available to authorized users.

Sarah Cogos

sarah.cogos@u-psud.fr

Samuel Roturier

samuel.roturier@u-psud.fr

Lars Östlund

lars.ostlund@slu.se

1 Ecologie Systématique Evolution, Univ. Paris-Sud, CNRS, AgroParisTech, Université Paris-Saclay, 91405 Orsay, France

2 Department of Forest Ecology and Management, Swedish University of Agricultural Sciences, 90183 Umeå, Sweden and space (Krebs et al. 2010; Pyke et al. 2010), on every inhabited continent for millennia (Bowman et al. 2011; Scott et al. 2016). The nineteenth century marked radical shifts in the Earth's fire regimes, linked with rapid socioeconomic changes, notably in the "Western" world where industrialization induced the development of modern forestry. Fire thus came to be seen as a threat for silvicultural resources, and fire suppression was widely applied in the forests of the USA, Europe, and its colonies. In some regions, the counterpart of fire suppression was the buildup of fuel loads in forests, leading to catastrophic wildfires (Pyne 1997; Pausas and Keeley 2009; Krebs et al. 2010; Bowman et al. 2011; Scott et al. 2016). From the 1960s, fire has been increasingly recognized as a natural disturbance essential for the functioning of many ecosystems and for maintaining biodiversity (Shlisky et al. 2007; Kuuluvainen et al. 2002; Pausas and Keeley 2009; Krebs et al. 2010). Over the last few decades, fire restoration measures have been taken in many forest areas using prescribed burning (Faulkner et al. 1989; Brown et al. 1991; Fernandes et al. 2013; Valkó et al. 2014), including the Scandinavian boreal forest (Eriksson et al. 2013). The objectives of prescribed burning today are focused mainly on fire hazard reduction 
and sustainable landscape management, including biodiversity conservation (Fernandes and Botelho 2003; Valkó et al. 2016). Hence, since the beginnings of forestry, managers had to make choices about how to deal with fire, influenced by advances in ecological sciences, including understanding of perturbation regimes and sustainable resource use.

In Sweden, since the 1990s, conservation burnings have been performed within nature reserves, and the Forest Stewardship Council (FSC) certification requires Swedish forestry companies to apply prescribed burning on $5 \%$ of their annual clear-cut area on dry-mesic forestland, for biodiversity conservation purposes (FSC 2013). One of the objectives stated by the FSC regarding prescribed burning is to obtain the "most natural way to mimic the fire perturbation" (FSC 2013; p 12). However, these ideas are not new, since as early as the 1880s in northern Fennoscandia, fire was already seen as a possible tool in forest management, though for different purposes than biodiversity conservation. The region was familiar with forest fires, which had significantly increased from the mid-1600s to the mid-1800s in relation to the arrival of southern settlers and their practice of burning forests to improve cattle grazing, and, to a lesser extent, slash-and-burn agriculture. When forestry became a major economic force during the industrial period, systematic fire control and suppression entailed a dramatic drop in the number of fires (Zackrisson 1977; Granström 1991; Lehtonen and Huttunen 1997; Niklasson and Granström 2000; Granström and Niklasson 2008; Wallenius 2011; Rolstad et al. 2017). However, the role of fire as a potential ally in boreal forest regeneration has been debated since the late 1800s within the Scandinavian forestry community (Holmgren 1959; Granström 1991; Nilsson and Wardle 2005). In the 1950-1960s, prescribed burning (Sw.: hyggesbränning) was carried out in Sweden for forest regeneration purposes, ultimately covering large areas. The method consisted of burning clear-cut forest stands to promote the natural regeneration of the forest, in view of its commercial exploitation. Across the whole country, on average about 35,000 ha was burned every year between 1952 and 1955, representing about $17 \%$ of the regeneration area, and up to 44,000 ha was burned during the peak year, 1953 (Uggla 1957). From the second half of the 1960s, however, prescribed burning was superseded by mechanical soil preparation (Granström 1991; Östlund et al. 1997).

The wide application of prescribed burning for forest regeneration purposes in the 1950-1960s in northern Sweden is today attributed to the influence of one of its strong advocates, Joel Efraim Wretlind (1888-1965), forest manager for the Malå district forests from 1920 to 1952 (Granström 1991; Pyne 1997; Fig. 1). Sometimes called "the father of prescribed burning" (Segerstedt 2015), or the "prophet of modern forestry" (Öckerman 1998), and now an emblematic person within northern Sweden's forestry community, his mission was

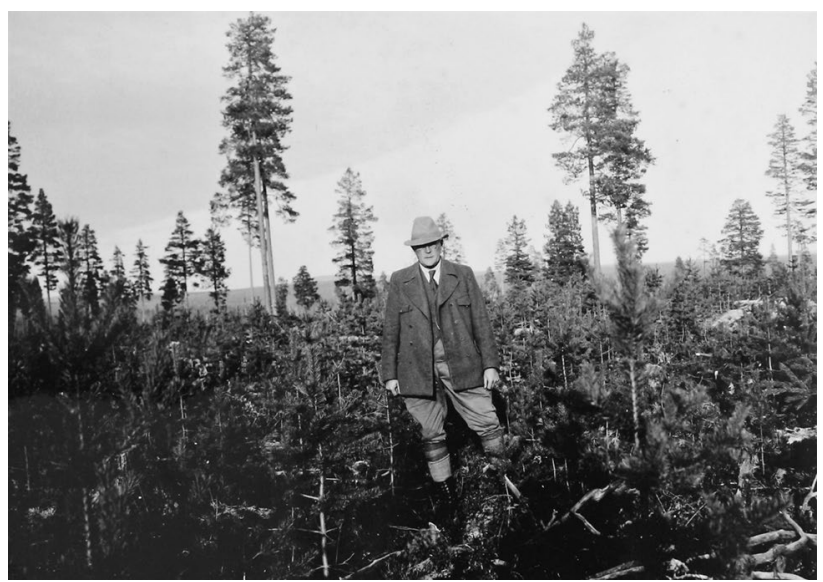

Fig. 1 Forest manager Joel E. Wretlind in 1947. Source: Table 1: W-photographs

to convince the Swedish forestry community to use prescribed burning as the preeminent regeneration tool. His influence still reverberates today, with the results of his methods showcased and debated within the forestry sector, and taken as a reference for today's prescribed burning. Thus, the broader history of fire management is intimately connected to the local history, which has been a driving force behind the evolutions of forestry in Scandinavia. Yet, no research has investigated Wretlind's motivations in detail, nor how he developed his methods, how they were received at the time, and how they translated into a unique fire regime. We argue that providing such a historical perspective would shed new light on fire management within Scandinavian forestry today. In this study, we sought to answer the following questions: (i) What role did Wretlind play in the development of prescribed burning in northern Sweden's forest management? (ii) What motivated Wretlind to use fire in forest management? (iii) How did Wretlind conduct prescribed burning, and how did that implementation influence local fire regimes? (iv) Can Wretlind's approach be considered a sustainable forestry precursor? The Swedish State Forest Company (Sveaskog AB, formerly Domänverket) holds Wretlind's writings and correspondence in its archives, representing a rich source of information that has not yet been consulted to any great extent. We have therefore examined this archive material, as well as records of forest management in the Malå district forests, and published literature, in order to answer our research questions.

\section{Methods}

\section{Study area}

The Malå district forests are located in Västerbotten County, Sweden, between $64^{\circ} 59^{\prime}$ and $65^{\circ} 31^{\prime}$, at an altitude of 
240-620 m. They are managed by the Swedish State Forest Company and were the responsibility of Wretlind as forest manager from 1920 to 1952. At that time, the district was divided into smaller management units (Sw.: kronoparker; Fig. 2), covering approximately 59,800 ha in 1954 (Wretlind 1955). The most abundant tree species today are Scots pine (Pinus sylvestris L.) and Norway spruce (Picea abies (L.) Karst.), and to a lesser extent birches (Betula spp.), aspen (Populus tremula L.), goat willow (Salix caprea L.), and rowan (Sorbus aucuparia L.). According to a 1949 forest inventory, lichen-rich forests, occurring mostly on the dry and oligotrophic soils of the flat lands along the main river valleys, formed $38 \%$ of the district's forests. $56.3 \%$ of the district comprised moss-rich mixed coniferous forests, with moister soil conditions, Norway spruce and birch present to a greater or lesser extent, and ground vegetation mostly composed of ericaceous dwarf shrubs such as bilberry (Vaccinium myrtillus L.) and lingonberry (Vaccinium vitis-idaea L.) (Wretlind 1955).

The first inhabitants of the area were the ancestors of the indigenous Sami people. The Sami forest reindeer herding community of Malå incorporates the entire Malå district. The Sami herders have year-round grazing land in the forest. Historically, the forest Sami lived off a combination of fishing, hunting, plant gathering, and reindeer herding, although the relative importance of these subsistence modes has varied over time and remains a subject of debate (Rautio 2014). When the Swedish settlers arrived in the area in the 1760s (Lundgren 1989), the Sami taxation lands covered the entire boreal forest landscape (Norstedt 2018). The Swedish settlers practiced agriculture (mostly cattle grazing), combined with fishing and hunting (Jonsson 1965; Lundgren 1989). They often chose land that had been burned by forest fire, which was more suitable for

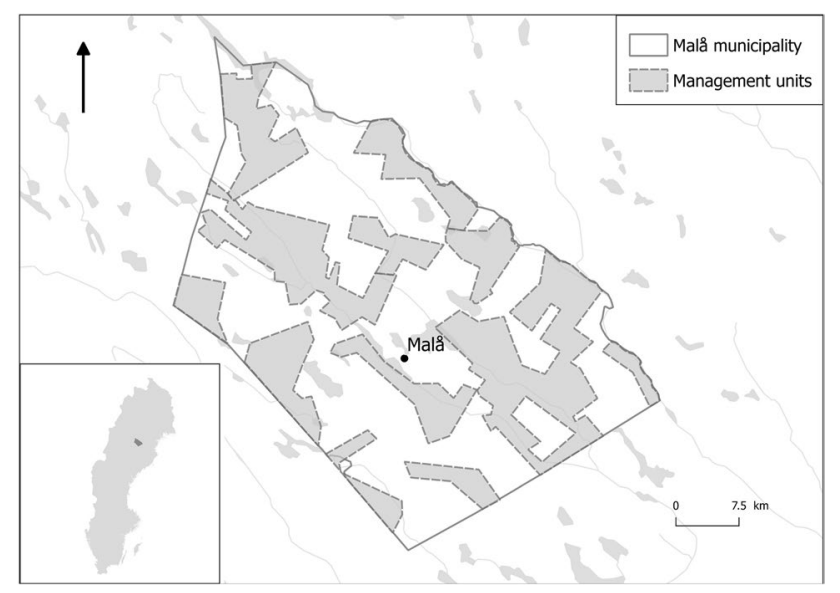

Fig. 2 Map of the state-owned forests in Malå district, comprising smaller management units (Sw.: kronoparker) within the Malå municipality in the 1950 s cultivation, or burned the land themselves to make it more fertile (Jonsson 1965). The first commercial forestry activity in the area started in the 1860s (Table 1: DV-M-SKUH-1959). The first logging carried out was high grade, i.e., selective logging of economically valuable trees.

\section{Archive sources}

Our research is based on the interpretation and analysis of a large number of historical records from the Swedish Regional State Archives in Härnösand, relating to Wretlind, and to fire management and prescribed burning in Malå district during the twentieth century. The data came from two separate archives: the State Forest Company's archive (Sw.: Domänverket) for Malå district, and Wretlind's personal archive (Table 1). The separate documents within the Wretlind archive are not registered; hence, we present each document used in this study under its name or topic, with the name of its corresponding file. Among the data collected from the State Forest Company's archive, the district's yearly reports display the total area burned each year through prescribed burning or natural and uncontrolled fires. Moreover, different types of data, depending on the source, were available for 415 stands burned between 1921 and 1970, such as the surface area of the burned stand for 291 of them, the dates of burning for 243 stands, and the forest type for 124 burned stands. Information about fire management was also available from letters exchanged between Wretlind and representatives of the National Board of Forestry (Sw.: Kungliga Skogsstyrelsen), the National Swedish Forest administration (Sw.: Kungliga Domänstyrelsen), and the Royal County Governor of Västerbotten (Sw.: Konungens Befallningshavande $i$ Västerbottens län). The Wretlind archive contained documents that Wretlind himself had conserved, including drafts and published versions of various reports that he had written, photographs and newspaper articles related to forest management, programs of excursions, and descriptions of experiments that he had carried out in the field. A detailed account of his experiments, methods, and results is also available in the form of recordings made between 1959 and 1960, and their transcriptions, which constitute the "forest testament" that Wretlind could not manage to write after his retirement in 1951 because of poor health. The archive material is all in Swedish, and the excerpts presented in this study have been translated by the authors. 


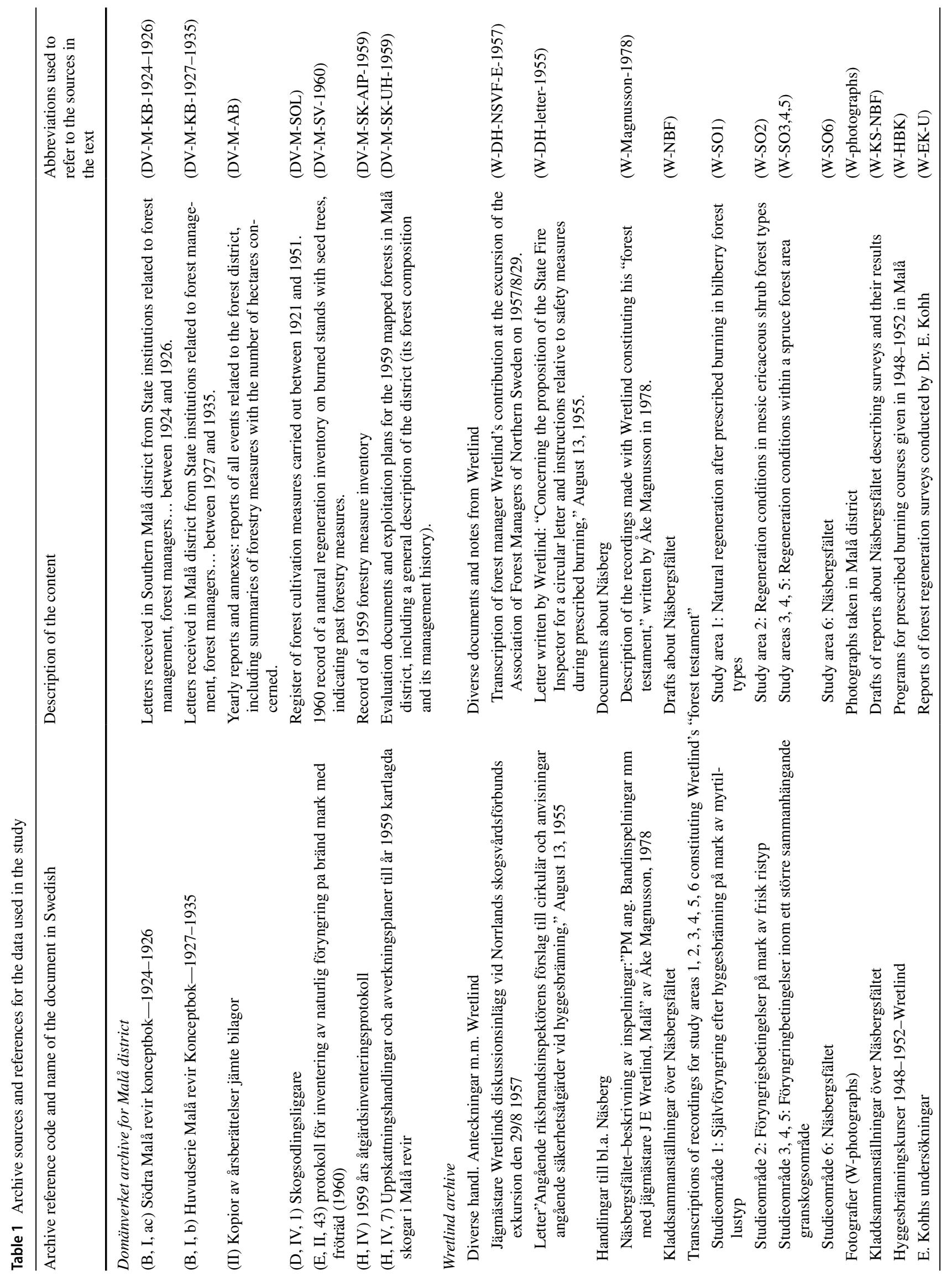




\section{Results and discussion}

\section{What was the role of forest manager Wretlind in the development of prescribed burning in northern Sweden?}

\section{Regenerating the boreal forest}

Even if Wretlind is considered to be the forerunner of prescribed burning in Sweden, the method had been used in northern Sweden as early as the 1880s. From the 1850 s onward, the Swedish boreal forest was increasingly considered to be mismanaged and "degenerated," from a forestry standpoint, because of exploitation practices that failed to ensure effective forest regeneration, notably high grading (Holmgren 1959; Granström 1991; Östlund and Roturier 2011; Lundmark et al. 2013). In 1883, the Swedish State Forest Agency called attention to the alarming state of the northern forests and initiated scientific investigations to solve the regeneration issue (Holmgren 1959). Fire had increasingly been seen as a threat to the growing forest industry and was controlled by an effective fire suppression system starting in the 1860s (Niklasson and Granström 2000; Kardell 2004; Wallenius 2011). Nevertheless, some forestry scholars and managers began to recognize the role of fire in the regeneration of Scots pine stands and to advocate using fire as a tool (Holmerz and Örtenblad 1886; Holmgren 1959; Granström 1991). Örtenblad argued that fire was indispensable for regeneration in old-growth spruce forest stands, as a soil preparation tool and as a way to provide light to the seedlings (Holmgren 1959). In Sweden, the results of comparative experiments launched by the government in the 1890s to clarify the regeneration potential of burned ground led to the application of burning as a forestry practice, followed by natural regeneration or sowing, in several districts in the northernmost Norrbotten County (Holmgren 1959; Granström 1991). Thus, foresters in Scandinavia came to realize early on that, once controlled and mastered, fire could be an ally in forest management. In the meantime, in the USA, the local burning practices were still judged severely by forestry scholars who strongly advocated fire suppression to preserve forests (Johnson and Hale 2002). In North America, the use of fire in land management was initially promoted in the 1930s, although the risks it represented for timber production discouraged the emergence of prescribed burning at first (Ryan et al. 2013). For the same reasons, prescribed burning had raised strong distrust within the Swedish forestry community from the start in the late 1800 s, largely because of the risk of triggering wildfires. Some of the prescribed fires on logged stands escaped control, which raised doubts among practitioners that the method could be carried out safely (Granström 1991). Moreover, wildfires had until then been a very frequent and problematic issue for the early forest industry: 29,000 ha of State Forest burned in forest fires in 1878 (Holmberg 2005) and another 50,000 ha in 1888. On the same day in 1888 , the cities of Umeå and Sundsvall also suffered fires, which did not help the cause for advocates of prescribed burning (Högbom 1934).

The expansion of Norway spruce over Scots pine in forests that had undergone high grading had been a strong argument in favor of burning during the late 1800s. However, Norway spruce started to acquire more economic value in the 1890s, which then swayed some of the previous advocates (Holmgren 1959; Granström 1991). Additionally, clear-cutting was experimented with as early as the $1880 \mathrm{~s}$ in some parts of Sweden, under the influence of German forestry (Lundmark et al. 2017), and began to be applied more widely in the early 1910s. It was supposed to be sufficient to ensure good conditions for forest regeneration and sustainable production (Holmgren 1959; Lundmark et al. 2017). In the early 1900s, burning began to be seen as a superfluous operation with no significant effect on regeneration. It then fell out of fashion and around 1910 was used much less in the national forests, being replaced by mechanical soil preparation methods followed by natural regeneration (Holmgren 1959). However, the results of the alternative methods were generally judged unsatisfactory (Holmgren 1959). This was the case in the Malå district, where attempts by the State Forest Company to develop regeneration methods after high grading, such as digging ditches and direct sowing on clearcut areas, gave poor results (Jonsson 1965).

\section{Proscribing prescribed burning}

When Wretlind took office in Malå in 1920 as chief forest manager, he discovered a forest unable to support sufficient regeneration (Wretlind 1932; Table 1: W-SO6). The year after he arrived in Malå, he established five study areas where he carried out forest regeneration experiments on several forest types (Table 1: W-Magnusson-1978). The first study area comprised bilberry-type stands, the second stands of mesic ericaceous shrub type, and areas three, four, and five comprised Norway spruce forest (Table 1: W-SO1, SO2, SO3, SO4, SO5). A sixth experimental area, Näsbergsfältet, provided the basis for the development of Wretlind's method (AssiDomän 1994) and has been described as "the apple of his eye" (Table 1: W-Magnusson-1978). In his "forest testament," Wretlind recounted how "horrified" he was when he discovered the state of the stands within the area, as indeed other foresters in the county had (Tirén 1937). The bigger Norway spruces had been logged in 1911-1913, while the Scots pines had been spared, as well as smaller Norway spruces and birches. 
After several years of high grading, the stands had been left half-bare. The ground vegetation had not undergone any major change and was mostly covered by a thick layer of moss (Table 1: W-SO6).

Wretlind's testament allows us to understand how he came to consider fire as a regeneration tool. Through empirical observations, and ground investigations on how natural forest stands arose (Table 1: W-SO5), as well as fire history investigations (Table 1: W-SO6), he concluded that most forests had regenerated after "beautiful natural fires" (Table 1: W-SO1, p 27). Observing the ineffective regeneration of previously logged stands over the years, Wretlind concluded that the stands would not regenerate without the help of fire (Table 1: W-SO1). Moreover, he knew about the farming practice of setting fire to the forest to create pasture for cattle (Table 1: W-SO6), and he "pondered the fact that the farmers' young forests could come as quickly as they did" (Table 1: W-SO6 p 15, band 11). About Näsbergsfältet, Wretlind recounted how the "outstandingly beautiful" stands on earlier burnings at the nearby Näsberg homestead (a private property owned by a farmer) encouraged him to use fire to regenerate this area (Table 1: W-SO6, p 16, band 9). $\mathrm{He}$ was also familiar with previous work that had fueled the debate on prescribed burning as a regeneration tool (Lundberg 1915; Holmgren 1917; Lindberg 1917), which he later referred to in his publications (Wretlind 1932). All this led him to experiment with new methods of forest regeneration and to initiate a radical transformation of the forestry practices in his district.

His first experimental burnings were performed in 1921 on both low-fertility Scots pine heaths and richer mossdominated stands (Table 1: DV-M-AB; Wretlind 1932). The treatment consisted of burning clear-cut stands to favor the regeneration of Scots pine, ensured mostly by natural regeneration through seed trees but also by sowing. Wretlind's experimental design also included unburned stands as controls. The approach to the burning consisted of first preparing and securing the stand, by protecting unsafe borders of the stand by digging firebreaks, burning anthills in advance because they could continue to burn for days, protecting seed trees by covering the bottom of their trunks with soil, and removing brush from around the seed trees (Wretlind 1932). As for the burning process itself, an initial strip was burned along a firebreak, to act as a barrier to the fire (Sw.: "skyddsavbränning”). During the early years of prescribed burning, the fire was then set to run free with the wind over the stand, starting from an opposite firebreak (Wretlind 1932). This method of letting the fire spread with the wind came to be referred to by Wretlind as "old fashioned" (Table 1: W-SO1). Later, the whole stand was preferably burned against the wind, in successive ignition strips starting from a firebreak, corresponding to the method today called strip head fire (Table 1: W-SO1; Wretlind 1948; Fig. 3).
Wretlind followed the development of regeneration on burned stands and compared different regeneration methods. For example, in 1926, he designed an experiment to compare the results of broadcast sowing and natural regeneration on burned stands (Table 1: W-NBF). In 1934, he began systematic surveys of several areas. He laid out transects and inventory plots in order to measure plant establishment and regeneration success (Table 1: W-SO6; W-SO2). Other forestry scientists also carried out research within the study areas, such as Dr. Elmar Kohh, who counted the tree seedlings and monitored the survival of plants in inventory plots after stand clearing on burned stands (Table 1: W-EK-U).

In 1932, about ten years after his first burnings, Wretlind published "About prescribed burning within Malå district" ["Om hyggesbränningarna inom Malå revir”], in which he summarized the objectives and principles of his method. His main argument in favor of prescribed burning was the difficulty in regenerating mesic, moss-rich forests with a thick "raw-humus" layer, i.e., with a ground layer of organic matter lying over the mineral soil, which covered large areas in the southern parts of Lapland (Table 1: W-SO6; Wretlind 1932). The main purposes of prescribed burning, used as a soil preparation tool, were thus to provide exclusive access to the nutrients for the tree seedlings by eliminating the moss layer and competing ground vegetation, but also to accelerate the transformation of the soil composition (Table 1: W-SO1; W-SO2; W-SO5). If stands were adequately burned, within a few years the soil turned into a compact mull humus, i.e., a soil where the mineral soil and organic matter are mixed, which is therefore fertile and suitable for ensuring growth of seedlings (Wretlind 1932). Wretlind argued that the regeneration of both Norway spruce forests and Scots pine heaths was significantly stronger and more promising on burned stands, although the results were less obvious for pine heath forest (Wretlind 1932). Thus, he believed that, if more experiments like his were carried out, prescribed burning would be seen as a sustainable, rational, often inevitable, soil preparation method for the degenerated forestlands of northern Sweden (Wretlind 1932). However, despite his intentions and his efforts to convince others, the technique raised a strong distrust within the professional forestry community (Jonsson 1965) and remained only marginally used during the 1930s (Ebeling 1959; Pyne 1997).

\section{From rejection to recognition}

Wretlind believed that the only reason prescribed burning had been used so little was a lack of understanding by people who had not actually participated in the process themselves, and who were misled about the risks burning represented for triggering wildfires (Wretlind 1932). Whatever the cause, when Wretlind started his experiments, burning was considered too risky, given the lack of experience of prescribed 
Fig. 3 Different steps of the prescribed burning system carried out under Wretlind: a burning anthills; $\mathbf{b}$ burning along a firebreak; $\mathbf{c}$ lighting the fire with a birch-bark torch; d Scots pine saplings growing around a seed tree. Source: Table 1: W-photographs
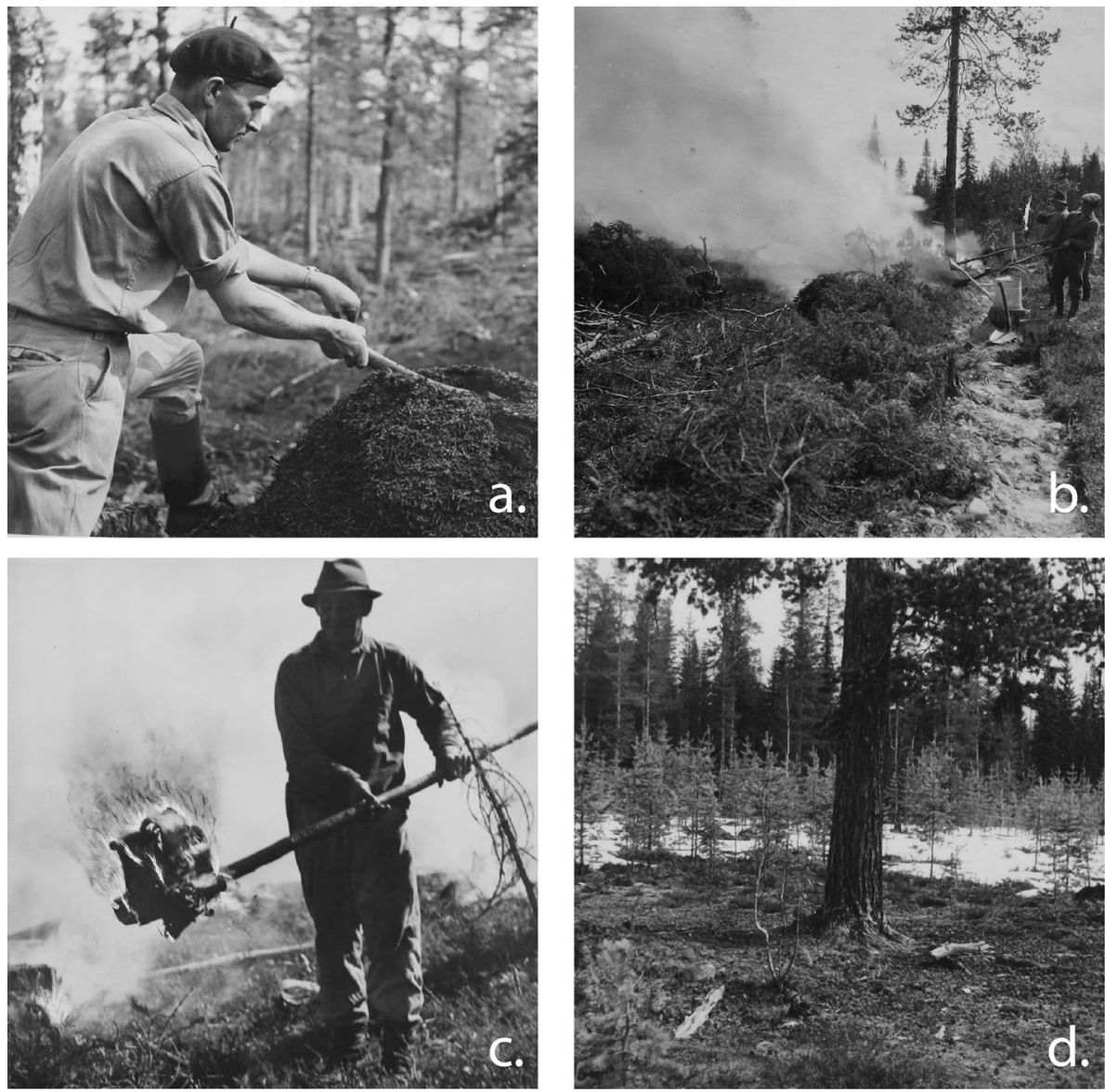

burning practitioners, and too expensive when carried out on small stands (Ebeling 1959). Both clear-cutting and prescribed burning were controversial methods that went against the watchword of carefulness that prevailed in the forestry industry at the time (Öckerman 1998). Wretlind had to convince his superiors, who were skeptical about his methods, that they were the only way to ensure forest regeneration in the interior of Lapland and to let him carry out his trials:

"(...) my chief forester at the State Forest at the time, the prominent Gustaf Borg, did not want to accept my point of view. He considered that we could not get any regeneration within a reasonable time in Malå district because of the altitude above sea level, the sparse seed years, etc., and that it appeared that no plants established on old burnings. On my side, I could not accept this point of view, because it had been proven that (...) we could, if a knowledgeable person took care of the land and could burn it as well as it is burned by forest fires, get a decent regeneration." (Table 1: W-SO1 p 35 , band 1 ).

Wretlind managed to get authorization from the State Forest Company to carry out his experiments, and, when the results of his burnings started to appear, he tried to convince his superiors of the success of his methods. In 1932, he was visited by the State Forest Company's general director and he showed him some of the experimental plots at Näsbergsfältet. At these plots, the young forest had grown "up to the nose" just nine years after burning. Wretlind recalled how the general director "thought that I was lying by attributing plant growth to fire" (Table 1: W-SO6, p 7, band 10).

Despite these achievements, Wretlind continued to be ignored in the Swedish forest regeneration debate. His temperament, described as "belligerent and quick to reply" (Ebeling 1959: p 416), did not help him convince skeptics about the validity of prescribed burning. For instance, in 1927, a forest manager in a neighboring district accused him of carrying out burning irresponsibly at the most risky time of the year for wildfires in a letter sent to the Royal County Governor of Västerbotten, thus revealing the distrust that Wretlind aroused among his counterparts (Table 1: DV-MKB-1927-1935). The 400 forest wildfires that burned about 8000 ha of productive forest in 1933 certainly did not help Wretlind's cause (Kardell 2004). He was left to wait for a more favorable period for his ideas to be accepted (Ebeling 1959). In the mid-1930s, he took a leave of absence to focus on his experiments full time for a few years and sought to 
become a senior lecturer (Table 1: W-SO1; Öckerman 1998). However, his academic essay when he applied for the position was severely criticized by the examiners and Wretlind's application was rejected. Failing to be recognized as a scientist, Wretlind took back his position as Malå district's manager (Öckerman 1998).

In the meantime, the 1930s witnessed a debate between the practitioners of a new forestry system advocating clearcutting, and those who retained the more traditional practice of selective logging, which was deeply rooted in northern Sweden, and where it remained the dominant logging method. Some forest managers, including Wretlind in Malå, dissented from this position and carried out clear-cutting on a small scale in their respective districts (Ebeling 1959; Lundmark et al. 2013). At the beginning of the 1940s, the failures of the high-grading system became obvious, especially at higher altitudes and northern latitudes. The successful forest regeneration in Malå district stood out as an exception in the northern forest, and in the early 1940s, conditions were finally right for Wretlind to prove the merits of his methods (Ebeling 1959; Granström 1991). As Ebeling (1959: 424) put it, "Mala district became during the last years of the 1940s a place of pilgrimage for the northern forestry menthe new Mecca of forest management (...)."

In this context, one event in particular contributed to the recognition and broad dissemination of prescribed burning: a field trip to Näsbergsfältet organized in 1947 by the Association of Forest Managers of Northern Sweden (Sw.: Norrlands Skogsvårdsförbund), and led by Wretlind (Wretlind 1955; Granström 1991; Öckerman 1998). The area was designed to display the results of experimental burnings that had been carried out since 1923, with an excursion trail across burned and control stands. Wretlind recounted the amazement of his colleagues when they discovered the abundance of plants in some burned stands (Table 1: W-SO6). His methods were then seen as the answer to the regeneration problems occurring in northern Sweden's inland forests (Öckerman 1998). Näsbergsfältet was later used as an experimental and educational site for the Swedish Forestry College (AssiDomän 1994), and today foresters still visit the area to observe Wretlind's methods and results (Lepikko 2018). Revealing his willingness to disseminate and promote his methods, in 1947 Wretlind organized the making of a film about prescribed burning in Malå (Table 1: W-SO1; Fig. 4). From 1948 to 1951, he also organized prescribed burning courses, including field trips to his study areas (Table 1: W-HBK). In 1948, he published "Northern Sweden's prescribed burning," which summarized his work and results, and gave detailed guidelines for the safe and effective use of prescribed burning. Between 1948 and 1958, he received about 2000 guests in Malå (Öckerman 1998), including foresters from outside Sweden, such as a team of Russians (Table 1: W-photographs).

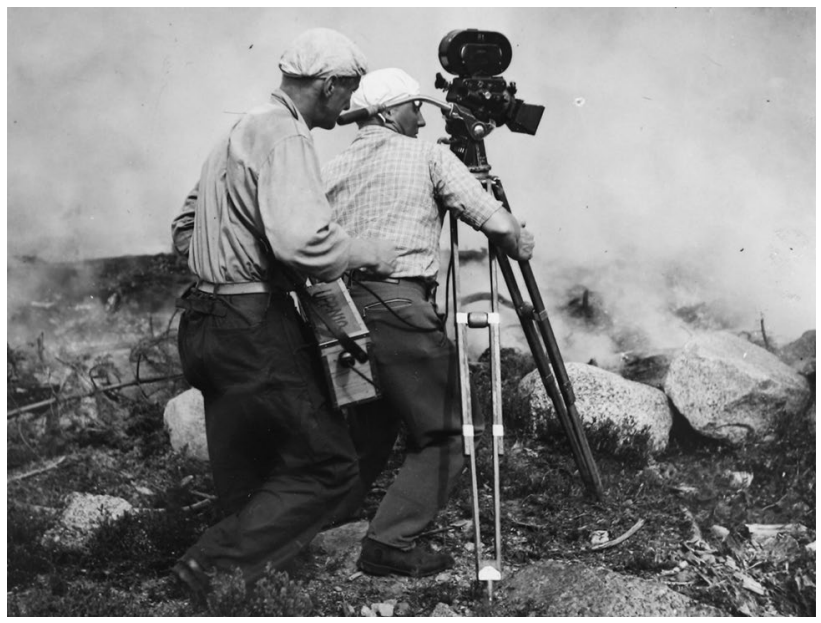

Fig. 4 A photograph taken during the filming of a movie in 1947 on prescribed burning in Malå: "Photographer Gustavson at the camera, and an assistant from Malå." Source Table 1: W-photographs

Even after he had proven himself, and after he retired in 1951, Wretlind continued to promote prescribed burning. For example, in 1955, Wretlind was asked to provide feedback on a circular letter about safety measures to be employed during prescribed burning. In his answer, Wretlind argued that prescribed burning had proven to be an indispensable regeneration measure and therefore should not be "either discredited or unnecessarily complicated by superfluous rules" (Table 1: W-DH-letter-1955). Irrespective of the debates and disagreements that Wretlind could trigger, he succeeded in convincing the forestry community, and in the following decades, his methods have been widely applied by both private owners and forestry companies in Malå district and also across the whole of northern Sweden (Jonsson 1965; Kardell 2004). Wretlind was made a member of the Royal Academy of Agriculture and Forestry, a commander of the Order of Vasa and an honorary doctor at the Royal Forestry Institute in 1957 (Öckerman 1998). He was recognized as the forerunner of the prescribed burning technique that came to be an essential step in the regeneration of northern Sweden's raw-humus forests (Ebeling 1959; Jonsson 1965).

\section{How did prescribed burning as advocated by Wretlind shape the fire regime in Malå?}

\section{Burned area and number of fires}

The total area burned every year through prescribed burning, but also through natural or uncontrolled forest fires, is recorded in the district's annual reports (Table 1: DV-M-AB; Fig. 5a). The first burnings were carried out in 1921, one year after Wretlind took his position in Malå. Between 1921 


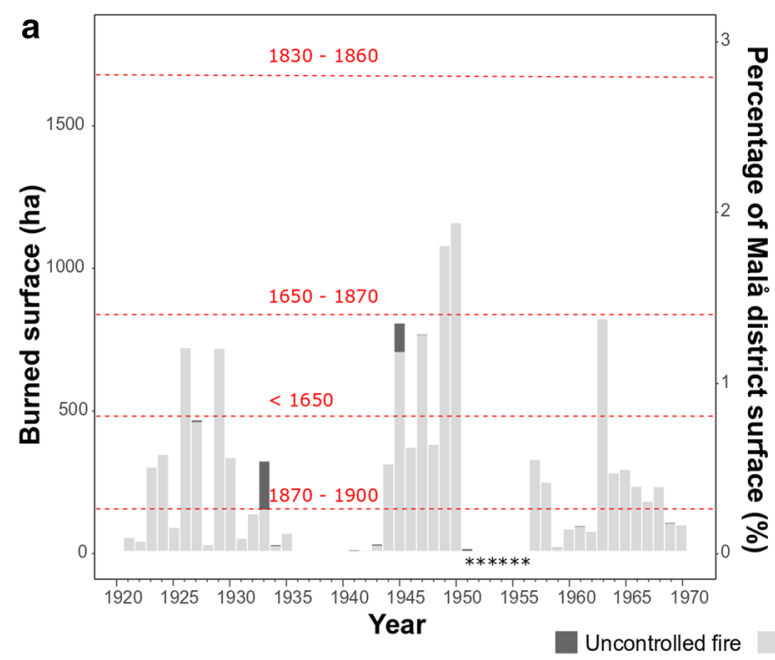

Fig. 5 a The total surface area burned through prescribed burning (light gray) and uncontrolled fires (dark gray) and $\mathbf{b}$ the number of fires attributed to prescribed burnings (light gray) and uncontrolled fires (dark gray), per year in Malå state-owned forests. The red dot-

and 1935, 3434 ha was burned through prescribed burning. The size of the burned area then fell in the mid-1930s, corresponding to the period when Wretlind took leave from his position and the period when clear-cutting and prescribed burning were most severely criticized. Burning started again in the 1940s, after Wretlind returned to his position and succeeded in convincing others of the efficiency of his technique, and covered significantly large areas. The drop in the 1950s coincided with Wretlind's retirement in 1952. Prescribed burning then started again in the second half of the 1950s, under the supervision of Wretlind's successors. The variations within each period arose because of more or less favorable conditions for burning, linked to the weather conditions during each summer.

According to the data gathered, at least 11,208 ha was burned through prescribed burning between 1921 and 1970, which represents $18.7 \%$ of the Malå state-owned forest. The mean total burned area per year during the entire period 1921-1970 was 255 ha \pm 300 , i.e., $0.43 \%$ of Malå stateowned forest. The mean total area burned during the period when Wretlind was active, and since he started his burnings in 1921, i.e., the periods $1921-1935$ and 1944-1950, was $357 \mathrm{ha} \pm 346.4$, representing $0.6 \%$ of the Malå state-owned forest. During the peak year, 1950, 1161 ha was burned, i.e., $1.9 \%$ of Malå state-owned forest. By comparison, Östlund et al. (1997) found that, in the Lycksele state forest (ca $50 \mathrm{~km}$ to the south) for the periods 1920-1940 and 1950-1960, prescribed burning affected only $1 \%$ of the area annually during peak years. In their study of fire history at an area located in a river valley about $140 \mathrm{~km}$ southeast of Malå, Niklasson and Granström (2000) calculated that on average

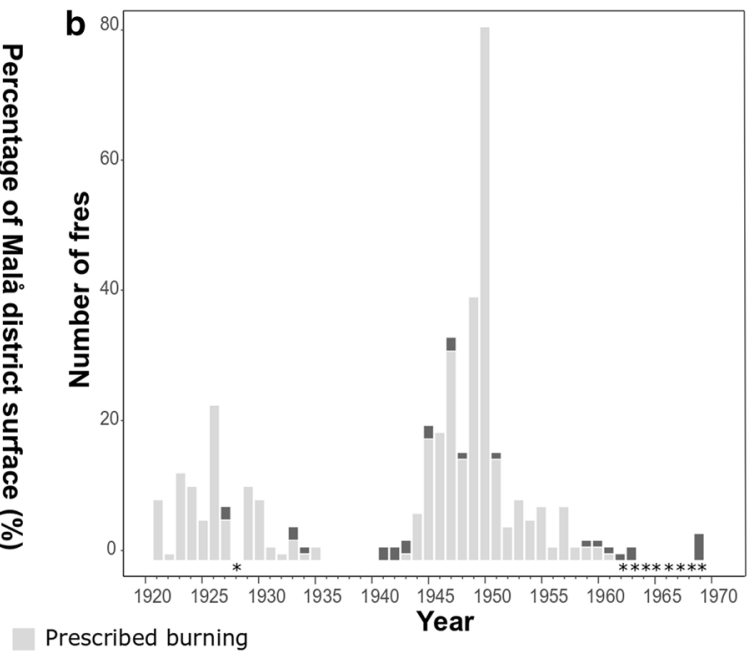

ted lines in a indicate historical levels of burned surface calculated by Niklasson and Granström (2000) for various periods. The stars indicate missing data for prescribed burning. (Color figure online)

$0.8 \%$ of their study area was burned each year prior to 1650 . This increased to $1.4 \%$ per year for the period $1650-1870$, reaching $2.8 \%$ per year during the period $1830-1860$, associated with a population increase and thus an increase in anthropogenic fires, and then dropped to $0.25 \%$ per year for the last decades of the 1800s. Assuming that the same pattern occurred in Malå, although the surface area affected by prescribed burning during 1921-1970 was uneven from year to year, the application of prescribed burning represented a significant increase in burned area compared with the last decades of the 1800s and in peak years almost reached the extent of the historical peak, i.e., the period 1830-1860 (Fig. 5a). It is also much higher than the present-day levels, since, today, fire affects only $0.006 \%$, of the Swedish forest per year, with a contribution of $65 \%$ of prescribed fires and $35 \%$ of wildfires (Ramberg et al. 2018).

The surface burned through natural, or uncontrolled fires, mostly as a result of escaped campfires or lightning, remained null or very low over the whole period in Malå district (Table 1: DV-M-AB). Almost the entirety of the burned area for the period 1916-1970, during which fire suppression was still the norm, is thus attributable to prescribed burning. The only case of prescribed burning escaping to cause a forest fire, affecting 6 ha of forest, was recorded in 1951 and, according to Wretlind's successor, was reportedly caused by "ignorant" private forest owners (Table 1: DV-M-AB).

According to data from the State Forest Company's archive (Table 1: DV-M-SOL; DV-M-SV-1960; DV-M-QKAIP-1959), the mean surface area of stands burned between 1921 and 1970 was 25 ha ( \pm 13.8$)$, with a minimum value of 
0.2 ha and a maximum value of 152 ha. Wretlind explained how the size of the burned stand mattered, particularly in determining the cost-effectiveness of the burning. It should be large enough to reduce the surveillance and transportation costs, compared to several smaller burnings, but small enough (below $40 \mathrm{ha}$ ) to allow the burning leader to keep control of the movements of the working team and control the fire intensity (Wretlind 1932, 1948). The number of fires that occurred each year as a result of either prescribed burning or uncontrolled fires (Fig. 5b) generally followed the same pattern as for the total burned area (although data are missing for some years). In Malå, 367 burnings were carried out in total for the period 1921-1961 according to the collected data, with an average number of burnings per year of $8.9 \pm 14.2$, and a maximum of 79 burnings in 1950. In their study area, Niklasson and Granström (2000) calculated the number of fires to be 0.095 fires $\left(10^{4} \mathrm{ha}\right)^{-1}$ year $^{-1}$ for the period $1350-1650$ and 1.17 fires $\left(10^{4} \mathrm{ha}\right)^{-1}$ year $^{-1}$ for the peak period 1840-1860. Comparatively in Malå, 1.5 burnings $\left(10^{4} \mathrm{ha}\right)^{-1}$ year $^{-1}$ took place during 1921-1961. Rolstad et al. (2017), in their study of fire history in an area located in the Norwegian boreal forest $\left(59^{\circ} 59^{\prime}-60^{\circ} 04^{\prime} \mathrm{N}\right)$, showed a trend for decreasing fire sizes for the period 1625-1800, which was associated with an increasing number of fires. In the later period, this trend was associated with an increasing population density in northern Scandinavia, resulting in more accidental forest fires, and slash-and-burn agriculture (Granström and Niklasson 2000; Rolstad et al. 2017). The pattern of fires induced through prescribed burning in Malå follows the same trend of more numerous and smaller fires, although the burning method was different and pursued different objectives, associated with commercial forest regeneration.

\section{Burned forest types}

Between 1921 and 1931, 91.6\% of the burned area comprised moss-rich forest (2821 ha) and 8.4\% Scots pine heath forest (259 ha) (Wretlind 1932), which were burned in the frame of Wretlind's research on pine heath regeneration (Wretlind 1955). According to inventories carried out in 1959 and 1960 (Table 1: DV-M-SK-AIP-1959; DV-MSV-1960), forest types that were burned the most between 1944 and 1960 were mesic forests with a ground vegetation dominated by ericaceous shrubs, such as bilberry and lingonberry (54.5\%), followed by mesic-humid ericaceous shrub forests (30.1\%). Thus, more than $90 \%$ of the burnings between 1921 and 1960 were performed on mesic and humid ericaceous shrub forests (Table A in online supplementary material). By comparison, Zackrisson (1977), in his study of the fire history of a river valley southeast of Malå, calculated that the mean fire frequency was 52.4 years for lichenCalluna forests, 58.0 years for Vaccinium vitis-idaea forests, and 90.8 years for Vaccinium myrtillus forests. Some Finnish studies found much longer fire intervals for the period prior to significant human influence than usually assumed in Fennoscandian boreal forests: over 200 years at dry heath forests sites (Pitkänen et al. 2002) and over 500 years for Norway spruce-dominated forests (Pitkänen et al. 2003). Either way, the fire management strategy in Malå during the prescribed burning era reversed the trend observed for the historical fire regime. Forest types where fire seldom occurred were treated with prescribed burning because they were hard to regenerate. By contrast, forest types that were historically most frequently affected by fire, notably lichen-rich Scots pine heaths, were spared from prescribed burning because they could regenerate without the help of fire, and thus benefited less from it (Östlund et al. 1997).

\section{Burning season}

Wretlind recommended carrying out prescribed burning as early as possible in the snow-free season, as soon as the ground was dry enough. The conditions required for successful burning therefore usually occurred around midJune. Because of the weather conditions, some burnings may have had to be delayed until midsummer, or even later in the summer, when the stand had become dry enough to support the fire (Table 1: W-SO1). The data from Domänverket archive, available for 236 stands burned during the period $1921-1951$, show that $28.9 \%$ of the burnings were carried out before 15 June, $44.9 \%$ between 15 June and 15 July, $19.1 \%$ between 15 July and 15 August, and $7.2 \%$ after 15 August. Granström (1993) calculated that lightning ignitions in boreal Sweden peak in late June and early July, with $12 \%$ of the ignitions occurring prior to 15 June and 3\% after 15 August. Drobyshev et al. (2012) found that, in northern Sweden, fires in the second half of the fire season (i.e., August) dominated the total area burned for the years 1996-2008, probably because of the declining water content of forest fuel accumulating over the summer. Prescribed burning under Wretlind's management thus induced a shift toward early season fires, with a higher proportion of ignitions occurring prior to 15 June compared with the natural ignition pattern, although most of the burnings still corresponded with the timing of natural ignition.

\section{Can Wretlind be considered as a precursor to a sustainable forestry system?}

The application of prescribed burning in Malå district from 1921 affected a fairly high proportion of the district's forestland and thus had a significant impact on the forest regeneration pattern. Associated with other forest regeneration practices, such as clear-cutting and the selection of seed trees on the burned stands, the prescribed burning management 
system favored a regeneration of Scots pine on stands that were previously dominated by Norway spruce (Östlund et al. 1997). Hence, we suggest that Wretlind's management created a new local fire regime, with previously unseen characteristics, driven by the objectives of commercial forestry, i.e., the fast and economically profitable regeneration of an even and homogeneous pine forest, which greatly modified the forest composition of the region. However, the documents conveying Wretlind's views toward the end of his career, and life, reveal a nuanced vision of forestry management, inspired by "nature's" processes, and valuing forest diversity and interactions between species, going against the dominant trend of his time (Table 1: W-SO1, W-SO2, W-SO3; W-SO5; W-SO6; W-DH-NSVF-E-1957).

Toward the end of Wretlind's career, artificial regeneration with collected seeds and seedlings (Sw.: skogskultur) and mechanical soil preparation were increasingly being used instead of natural regeneration from seed trees following prescribed burning. Once effective machines were developed in the 1950s, mechanical soil preparation became cheaper than burning, and more convenient because it could be applied at any time, regardless of the weather conditions (Kardell 2004). However, the results of his regeneration with seed trees, where the plants grew with "increased speed and increased strength," 30 years after his first burnings, made Wretlind "very skeptical" about the possibility of regenerating mesic stands with the same efficiency without fire in northern Sweden's highlands (Table 1: W-SO2, p 24, band 5; W-DH-NSVF-E-1957; W-SO1). To him, in view of the productivity of Norway spruce forests established everywhere after natural fires, mechanical soil preparation was no more than a "very audacious experiment" (Table 1: W-SO4, p 34). Wretlind thus stood against this trend, which he even called an "artificial regeneration epidemic" (Table 1: W-DH-NSVF-E-1957, p 4.a). Based on the results of his comparative surveys of artificial and natural regeneration, he tried to convince his counterparts that such sowing practices could only entail economical losses (Table 1: W-SO1; $\mathrm{W}-\mathrm{SO} 2$ ), and represented a "wasted artificial regeneration, a useless artificial regeneration" (Table 1: W-SO2, p 18, band 5).

Wretlind's deep trust that burning should be used as the foremost soil preparation method was rooted in his conviction that forestry had to reproduce nature's processes, because to him, "nature [could] do what we cannot" (Table 1: W-DH-NSVF-E-1957, p 3), and that this was not incompatible with objectives of forest productivity. To Wretlind, following nature was the best option in terms of forest regeneration and thus in terms of profitability. He considered the "natural soil preparation that nature itself had used" in northern Sweden's uplands as the only way to obtain "at least as beautiful forests as nature forests have given us" (Table 1: W-SO4, p 34).
He believed that what happened in nature could be reproduced by following "nature's directives" (Table 1: W-SO5, p 64), and his observations inspired him to improve his methods (Table 1: W-DH-NSVF-E-1957). Thus, there was no reason to be surprised at the remarkable results of prescribed burning in terms of forest regeneration, because the method was inspired by "nature's style" (Table 1: W-SO5, p 78). Furthermore, Wretlind sometimes invoked God as the hand behind nature's work. For example, he judged the results of artificial regeneration "quite pitiful" compared with the "natural forests God gave to us after fire" (Table 1: W-DH-NSVF-E-1957, p 4). He also referred to the blackened layer of humus resulting from a burning, protecting the plants from growing too early after the fire, as "God's protection against early sowing" (Table 1: W-SO6, p 14, band 10). His deep conviction regarding his methods can be seen in heated exchanges with Lars Tirén (a leading forest manager and researcher at the time) during the 1957 field trip by the Association of Forest Managers of Norrland, when the two men expressed their opposing views on forest regeneration and prescribed burning (Table 1: W-DH-NSVF-E-1957). One evocative excerpt of these exchanges comes from a 1958 press article:

“'Burn and let Our Lord handle the rest', meant honorary forestry doctorate Joel Wretlind, Malå, while professor Lars Tirén, raising a smile, pointed out that it was possible to expect the help of Our Lord in forestry without necessarily burning" (Table 1: W-photographs).

Compared with his earlier writings, documents conveying Wretlind's ideas toward the end of his life depict a more systemic vision of the forestry production system, where every species was needed and had a role to play that did not necessarily go against the aims of modern forestry. Wretlind based his ideas on his detailed and evergrowing knowledge of the ecology of the boreal forest species. Thus, he argued for a diverse forest, a vision going against the ideal of pure pine stands dominant in forestry at the time. For example, he argued for the conservation of trees that it was not economic to remove, because they did not prevent forest regeneration, but also for their biological and esthetic values (Table 1: W-SO4). Furthermore, the progressive elimination of Norway spruce in favor of monospecific Scots pine forests as a result of regeneration methods represented to him a "tremendous loss for most lands" (Table 1: W-SO1, p 19, Band 1). He also saw an economic interest in the preservation of Norway spruce, as without its contribution, the pines would stay twiggy and the wood would be of lesser quality (Table 1: W-SO1). That is why he started, from 1946, to sow Norway spruce after prescribed burning, with promising results (Table 1: W-SO1). 
He stood once again counter to current opinion when he opposed the "war" against birch, which in the 1950s was carried out in many districts (Table 1: W-SO1; W-SO6) and which he called a "wave of madness" (Table 1: W-SO5, $\mathrm{p}$ $83)$. Birch was considered a hindrance to regeneration, and the use of herbicide against it developed quickly in the 1950s (Kardell 2004). Wretlind admitted that in his early years as a forest manager, he also was "scared of the birch" and used to $\log$ it on regenerating stands. However, he soon realized that the species was becoming increasingly rare, and that a stand mixed with birch actually promoted better conditions for the humus layer forming within the young forest. Thus, he argued for the preservation of birch on regenerating stands, and this is still a debated subject today (Mård 1995; Hynynen 2011). To Wretlind, this was another argument for prescribed burning, because he considered that, without the help of fire, birch, and especially curly birch (Betula pendula Roth. var. carelica), was "doomed to die out because it [was] a true fire species" (Table 1: W-SO2 p 11, band $6)$. He also came to see the development of species such as fireweed (Chamerion angustifolium (L.) Holub) and wavy hair-grass, which come up after burning and which were considered as "bad weeds" by other foresters, who therefore used herbicides to get rid of them, as a "tremendous benefit" to forest regeneration (Table 1: W-SO2, p 11, band 6). His observations and his plant regeneration surveys after burning showed that Scots pine seeds established mostly around grass tufts, which provided a "nice growth bed," and that Scots pine plants developed most richly around such tufts (Table 1: W-SO2, p 11, band 7). Moreover, he believed that wavy hair-grass roots decaying in the underlayer of the soil contributed to the soil's productivity (Table 1: W-SO2, p 11, band 7). Thus, Wretlind argued:

"The fact that I have had a durably better benefit for the growth on my burnings compared to unburned stands is in great part due to the stand's flora that I see as a chance and not as an affliction. Those who set poison to kill it, yes, well, they should take it themselves" (Table 1: W-SO2, p 11, band 7).

To help control the proliferation of certain plant species, Wretlind began to consider other management factors, including grazing, and especially reindeer grazing, which made the use of herbicides redundant in reindeer herding areas. Indeed, Wretlind argued that summer reindeer grazing in bilberry-rich mesic forests that had been burned provided a control mechanism for the proliferation of "leaves," principally birch trees and wavy hair-grass, and was thus "particularly favorable" for regeneration (Table 1: W-SO1; W-SO6, p 15, band 11). As a result, he claimed that he had not had "any difficulties with the leaves at all" (Table 1: $\mathrm{W}-\mathrm{SO} 2$, p 11, band 7). An enclosure experiment helped convince him of the positive effects of grazing for forest regeneration: While the enclosure was full of birch, preventing regeneration, outside the enclosure, where reindeer, and probably other herbivores, could graze, it was completely birch free (Table 1: W-SO6). This example highlights what may appear to be a contradiction in Wretlind's discourse: While he praised the value of birch and warned against its disappearance, he also valued the role of reindeer in controlling its proliferation. This can be taken as another sign of his conviction that natural processes should be favored over artificial methods, and of his understanding of the complex interactions that occur within the boreal forest, where both the reindeer and the birch have their place. Furthermore, Wretlind came to adapt his application of prescribed burning to the presence of reindeer, as shown in a report he wrote for a popular course organized in 1954 about "Reindeer herding and the modern Norrland's forestry" (Wretlind 1955). He considered that reindeer herding rendered the burning of Scots pine heaths "unnecessary," because the thin grazed lichen mat allowed pine regeneration to establish easily compared with areas where reindeer herding was absent and the lichen mat thicker (Wretlind 1955, p 31; Table 1: W-SO2). The positive effect of reindeer grazing on Scots pine growth has since been suggested in scientific studies (Macias Fauria et al. 2008).

\section{Conclusion}

Our research, based on historical documents from the State Forest Company's archive, and Wretlind's personal archive, has allowed us to trace the evolution of Wretlind's ideas and the basis of his methods, as well how his method materialized in terms of burned surface and forest type. Based on detailed observations of the boreal forest ecosystem, complemented by systematic investigations, and knowledge of the forest literature at the time, Wretlind developed a comprehensive system of forest regeneration based on prescribed burning. He was initially met with hostility from his counterparts regarding his methods and often went against the dominant opinions of his time. He stood out as a self-made academic fighting other academics. However, his determination to prove the validity of his methods paid off when the Swedish forestry became desperate to find an efficient way to restore the forests. Applied at a large scale, his burnings have affected a substantial proportion of the forests in Malå district, and we have seen how Wretlind created a new forestry-driven fire regime that bore similarities with previous semi-natural fire regimes. Besides, his impact also spread beyond Malå, and his work changed forest management all over northern Sweden. Prescribed burning was applied in the whole of northern Sweden during the 1950s-1960s, and the methods used today for prescribed burning are directly descended from those developed during Wretlind's "era." 
Thus, not only does the case of Wretlind and Malå district illustrate the twists and turns of the history of fire management within forestry, it is also a core element to understand this history in Sweden during the twentieth century.

Nevertheless, Wretlind's methods based on natural regeneration after burning were replaced by mechanical soil preparation and planting of Scots pine monocultures. Toward the end of his life, Wretlind stood against these evolutions, which went against his own methods. Known for having promoted large-scale clear-cutting, his engagement with a more "natural" forestry system, conveyed in his latest written accounts, is less known. Wretlind was convinced that reproducing "nature's ways" was the best option to ensure forest regeneration. On those grounds, he defended natural regeneration with the aid of fire instead of artificial regeneration and developed a conception of a systemic forestry management, praising diversity, interaction, and cohabitation of species. While his later views about forestry, explained in detail in his never-published "forest testament," were not embraced by the forestry community at the time, they converge with the recommendations that were developed about 40 years later in favor of sustainable forestry. We therefore suggest that, on top of being considered as the forerunner of prescribed burning in Sweden, Wretlind may also be recognized as an early proponent of eco-forestry.

Acknowledgements Open access funding provided by Swedish University of Agricultural Sciences. We thank the Swedish Regional State Archive (Arkivcentrum Nord) in Härnösand and particularly John-Erik Hansson for his help in navigating the archive files. SEES-editing corrected the written English, and anonymous reviewers provided valuable comments that improved the manuscript's scientific content. This work was supported by the Carl-Göran Adelswärds stiftelse, the ÖMSE Program funded by the French Institute in Sweden, the French Engineering School AgroParisTech, and Formas, Sweden, under Grant 942-2015-556.

\section{Compliance with Ethical Standards}

Conflict of interest The authors declare that they have no conflict of interest.

Open Access This article is distributed under the terms of the Creative Commons Attribution 4.0 International License (http://creativeco mmons.org/licenses/by/4.0/), which permits unrestricted use, distribution, and reproduction in any medium, provided you give appropriate credit to the original author(s) and the source, provide a link to the Creative Commons license, and indicate if changes were made.

\section{References}

\section{Published sources}

AssiDomän (1994) I Wretlinds fotspår på Näsbergsfältet. AssiDomän Skog \& Trä AB, Lycksele skogsförvaltning (in Swedish)
Bowman DMJS, Balch J, Artaxo P, Bond WJ, Cochrane MA, D'Antonio CM, Defries R, Johnston FH, Keeley JE, Krawchuk MA et al (2011) The human dimension of fire regimes on Earth. J Biogeogr 38:2223-2236

Brown PJ, Manders PT, Bands DP, Kruger FJ, Andrag RH (1991) Prescribed burning as a conservation management practice: a case history from the Cederberg mountains, Cape Province, South Africa. Biol Cons 56:133-150

Drobyshev I, Niklasson M, Linderholm HW (2012) Forest fire activity in Sweden: climatic controls and geographical patterns in 20th century. Agric For Meteorol 154-155:174-186

Ebeling F (1959) Skogarna och deras vård i övre Norrland från och med 1930-talet. In: Arpi G (ed) Sveriges skogar under 100 år. En sammanfattande redogörelse över det svenska skogsbruket 1859-1959. Kungl. Domänstyrelsen, Stockholm, pp 413-443 (in Swedish)

Eriksson A-M, Olsson J, Jonsson BG, Toivanen S, Edman M (2013) Effects of restoration fire on dead wood heterogeneity and availability in three Pinus sylvestris forests in Sweden. Silva Fenn 47:954

Faulkner JL, Clebsch EEC, Sanders WL (1989) Use of prescribed burning for managing natural and historic resources in Chickamauga and Chattanooga National Military Park, USA. Environ Manage 13:603

Fernandes PM, Botelho HS (2003) A review of prescribed burning effectiveness in fire hazard reduction. Int J Wildland Fire 12:117-128

Fernandes PM, Davies GM, Ascoli D, Fernández C, Moreira F, Rigolot E et al (2013) Prescribed burning in southern Europe: developing fire management in a dynamic landscape. Front Ecol Environ 11:e4-e14

FSC (Forest Stewardship Council) (2013) The contribution of FSCcertification to biodiversity in Swedish forests. Report 2

Granström A (1991) Elden I människans tjänst. Skog Forsk 4:6-12 (in Swedish)

Granström A (1993) Spatial and temporal variation in lightning ignitions in Sweden. J Veg Sci 4:737-744

Granström A, Niklasson M (2008) Potentials and limitations for human control over historic fire regimes in the boreal forest. Phil Trans R Soc B 363:2353-2358

Högbom AG (1934) Om skogseldar förr och nu och deras roll i skogarnas utvecklingshistoria. Norrlandskt handbibliothek XIII. Almquist and Wiksell, Uppsala (in Swedish)

Holmberg L-E (2005) Skogshistoria år från år 1177-2005-Skogspolitiska beslut och andra viktiga händelser i omvärlden som påverkat Skogsvårdsorganisationens arbete. Skogsstyrelsen. Rapport 5 (in Swedish)

Holmerz CC, Örtenblad T (1886) Om Norrbottens skogar. Bidrag till Domänstyrelsens underaniga berättelse rörande skogsväsendet (in Swedish)

Holmgren A (1917) Föryngringsavverkning i Norrlands skogarna. Skogar och Skogsbruk. Studier tillägnade Frans Kempe. Bil. 1 till Skogsvårdsföreningens tidskr. 1917, p 149 (in Swedish)

Holmgren A (1959) Skogarna och deras vård i Övre Norrland intill år 1930. In: Arpi, G. (Ed.), Sveriges skogar under 100 år. En sammanfattande redogörelse över det svenska skogsbruket 1859-1959. Kungl. Domänstyrelsen, Stockholm, pp 375-412 (in Swedish)

Hynynen J, Repola J, Mielikäinen K (2011) The effects of species mixture on the growth and yield of mid-rotation mixed stands of Scots pine and silver birch. Forest Ecol Manag 262:1174-1183

Johnson AS, Hale PE (2002) The historical foundations of prescribed burning for wildlife: Southeastern perspective. In: Ford WM, Russel KR, Moorman CE (ed) The role of fire in nongame wildlife management and community restoration: traditional uses and new 
directions proceedings of a special workshop. USDA Forest Service Northeastern Research Station, Newton Square, PA

Jonsson J (1965) Jordbruk och binäringar. In: Jonsson J, Uggleberg G (ed) Malå Socken. Malå Hembygsförening (in Swedish)

Kardell L (2004) Svenskarna och Skogen, del 2, Från baggböleri till naturvård. Skogsstyrelsen, Jönköping (in Swedish)

Krebs P, Pezzatti GB, Mazzoleni S, Talbot LM, Conedera M (2010) Fire regime: history and definition of a key concept in disturbance ecology. Theor Biosci 129:53-69

Kuuluvainen T, Aapala K, Ahlroth P, Kuusinen M, Lindholm T, Sallanaus T, Siitonen J, Tukia H (2002) Principles of ecological restoration of boreal forested ecosystems: Finland as an example. Silva Fenn 36:409-422

Lehtonen H, Huttunen P (1997) History of forest fires in eastern Finland from the fifteenth century AD - the possible effects of slashand-burn cultivation. Holocene 7:223-228

Lindberg F (1917) Hyggesbränning. Skogen (in Swedish)

Lundberg G (1915) Om skogseld, dess förebyggande och bekämpade. Skogsvårdsföreningens tidskr, p 128 (in Swedish)

Lundgren A (1989) Malå, en resa från istid till framtid. Malå kommun (in Swedish)

Lundmark H, Josefsson T, Östlund L (2013) The history of clearcutting in northern Sweden-driving forces and myths in boreal silviculture. Forest Ecol Manag 307:112-122

Lundmark H, Josefsson T, Östlund L (2017) The introduction of modern forest management and clear-cutting in Sweden: Ridö State Forest 1832-2014. Eur J Forest Res 136:269-285

Macias Fauria M, Helle T, Niva A, Posio H, Timonen M (2008) Removal of the lichen mat by reindeer enhances tree growth in a northern Scots pine forest. Can J Forest Res 38:2981-2993

Mård H (1995) The influence of a birch shelter (Betula spp) on the growth of young stands of Picea abies. Scand J Forest Res $11: 343-350$

Niklasson M, Granström A (2000) Numbers and sizes of fires: longterm spatially explicit fire history in a Swedish boreal landscape. Ecol 81:1484-1499

Nilsson M-C, Wardle DA (2005) Understory vegetation as a forest ecosystem driver: evidence from the northern Swedish boreal forest. Front Ecol Environ 3:421-428

Norstedt G (2018) A land of one's own. Sami resource use in Sweden's boreal landscape under autonomous governance. Doctoral thesis, Swedish University of Agricultural Sciences, Umeå, Sweden

Öckerman A (1998) Joel Wretlind på Malå revir. In: Johansson M (ed), Miljöhistoria idag och imorgon. Karlstad: centrum för historiskfilosofisk forskning (in Swedish)

Östlund L, Roturier S (2011) Forestry historical studies in the province of Västerbotten, Northern Sweden: a review of Lars Tirén (1937). Scand J Forest Res 26:91-99

Östlund L, Zackrisson O, Axelsson A-L (1997) The history and transformation of a Scandinavian boreal forest landscape since the 19th Century. Can J Forest Res 27:1198-1206

Pausas J, Keeley J (2009) A burning story: The role of fire in the history of life. Bioscience 59:593-601

Pitkänen A, Huttunen P, Jungner H, Tolonen K (2002) A 10000 year local forest fire history in a dry heath forest site in eastern Finland, reconstructed from charcoal layer records of a small mire. Can J Forest Res 32:1875-1880

Pitkänen A, Huttunen P, Tolonen K, Jungner H (2003) Long-term fire frequency in the spruce dominated forests of the Ulvinsalo strict nature reserve, Finland. Forest Ecol Manag 176:305-319

Pyke DA, Brooks ML, D’Antonio C (2010) Fire as a restoration tool: a decision framework for predicting the control or enhancement of plants using fire. Restor Ecol 18:274-284

Pyne SJ (1997) Vestal Fire: an environmental history, told through fire, of Europe and Europe's encounter with the world. University of Washington Press, Seattle and London
Ramberg E, Strengbom J, Granath G (2018) Coordination through databases can improve prescribed burning as a conservation tool to promote forest biodiversity. Ambio 47:298-306

Rautio AM (2014) People-Plant Interrelationships. Historical Plant Use in Native Sami Societies. Doctoral thesis, Swedish University of Agricultural Sciences, Umeå, Sweden

Rolstad J, Blanck Y-L, Storaunet KO (2017) Fire history in a western Fennoscandian boreal forest as influenced by human land use and climate. Ecol Manag 87:219-245

Ryan KC, Knapp EE, Varner JM (2013) Prescribed fire in North American forests and woodlands: history, current practice, and challenges. Front Ecol Environ 11:e15-e24

Scott AC, Chaloner WG, Belcher CM, Roos CI (2016) The interaction of fire and mankind: introduction. Philos Trans R Soc B 371:201550162

Shlisky A, Waugh J, Gonzalez P, Gonzalez M, Manta M et al (2007) Fire, ecosystems and people: threats and strategies for global biodiversity conservation. The Nature Conservancy, Arlington

Tirén L (1937) Forestry historical studies in the Degerfors district of the province of Västerbotten. Meddelanden från Statens Skogsförsöksanstalt 30:67-322

Uggla E (1957) Mark-och lufttemperatur vid hyggesbränning samt eldens inverkan på vegetation och humus. Norrlands Skogsvårdsförbunds Tidskrift 1957:443-500 (in Swedish)

Valkó O, Török P, Deák B, Tóthmérész B (2014) Prospects and limitations of prescribed burning as a management tool in European grasslands. Basic Appl Ecol 15:26-33

Valkó O, Deák B, Magura T, Török P, Kelemen A, Tóth K, Horváth R, Nagy DD, Debnár Z, Zsigrai G, Kapocsi I, Tóthmérész B (2016) Supporting biodiversity by prescribed burning in grasslands-a multi-taxa approach. Sci Total Environ 572:1377-1384

Wallenius T (2011) Major decline in coniferous forests-reconstructing the phenomenon and seeking for the cause. Silva Fenn 45:139-155

Wretlind JE (1932) Om hyggesbränningarna inom Malå revir. Norrlands Skogsvårdsförbunds tidskrift, pp 243-331 (in Swedish)

Wretlind JE (1948) Nordsvensk hyggesbränning. Stockholm (in Swedish)

Wretlind JE (1955) Om den moderna nordsvenska skogshanteringen och renskötseln enligt undersökningar inom Malå revir. In: Renskötseln och den nutida norrländska skogshanteringen. Meddelande 3. Lappväsendet-Renforskningen (in Swedish)

Zackrisson O (1977) Influence of forest fires on the North Swedish boreal forest. Oikos 29:22-32

\section{Web sources}

Lepikko K (2018) Hyggesbruk och annat hett på årets höstexkursion. Skogen. Consulted in February 2019. https://www.skogen.se/ nyheter/hyggesbruk-och-annat-hett-pa-arets-hostexkursion (in Swedish)

Segerstedt R (2015) Kalhyggets fader nära att få sparken för sina hyggesbruk. Land Skogsbruk. Consulted in September 2018. https:// www.landskogsbruk.se/skog/kalhyggets-fader-nara-att-fa-spark en-for-sina-hyggesbruk/ (in Swedish)

Publisher's Note Springer Nature remains neutral with regard to jurisdictional claims in published maps and institutional affiliations. 